\section{Vaticanol C, a Novel Resveratrol Tetramer, Inhibits Cell Growth through Induction of Apoptosis in Colon Cancer Cell Lines}

\author{
Tetsuro Ito, ${ }^{a}$ Yukihiro AKaO, ${ }^{*}, b$ Toshiyuki TANaka, ${ }^{c}$ \\ Munekazu IINUMA, ${ }^{c}$ and Yoshinori NozAwA ${ }^{b}$
}

Gifu Pharmaceutical University, ${ }^{a}$ 5-6-1 Mitahora-higashi, Gifu 502-8585, Japan, Gifu International Institute of Biotechnology, ${ }^{b}$ Mitake, Gifu 505-0116, Japan, and Gifu Prefectural Institute of Health and Environmental Sciences, ${ }^{c}$ 1-1 Naka-fudogaoka, Kakamigahara 504-0838, Japan.

Received September 27, 2001; accepted November 8, 2001

A novel resveratrol tetramer, vaticanol $C$, isolated from the stem bark of Vatica rassak markedly suppressed cell growth through induction of apoptosis, which was characterized by nuclear changes and DNA ladder formation, in three different human colon cancer cell lines.

Key words vaticanol C; apoptosis; human colon cancer cell; cell growth; stilbenoid; Vatica rassak

In our phytochemical research on biologically active stilbenoid derivatives, the structures of resveratrol oligomers ranging from dimer to octamer in some species of Dipterocarpaceae, Vitaceae, and Leguminosae were characterized and the cytotoxic activity against human tumor cell lines in some stilbenoids was explored. ${ }^{1-5)}$ Among them, two representative resveratrol tetramers, vaticanols B (1) and C (2), were obtained from three Dipterocarpaceous plants ${ }^{3-5)}$ as the major products (Fig. 1). Thirty-five stilbenoid derivatives including $\mathbf{1}$ and $\mathbf{2}$ were evaluated for in vitro cytotoxicity in comparison with resveratrol (3). The most potent $\mathbf{2}$ inhibited cell growth at $5 \mu \mathrm{g} / \mathrm{ml}$ through induction of apoptosis in various human tumor cell lines. Herein we report the effect of $\mathbf{2}$ on the cell growth of human colon cancer cell lines SW480, DLD-1, and COLO201.

Compounds $\mathbf{1}-\mathbf{3}$ were isolated from the stem bark of Vatica rassak. ${ }^{3)}$ The isolation procedure and spectroscopic data of these were described in a previous paper. ${ }^{3)}$ Both vaticanols $(\mathbf{1}, \mathbf{2})$ are composed of four resveratrol units (Res. A-Res. D). The sequence of Res. A, for example, is ring $\mathrm{A}_{1}-\mathrm{C}-7 \mathrm{a}-\mathrm{C}-$ 8a-ring $\mathrm{A}_{2}$, as shown in Fig. 1.

Three human cancer cell lines were grown in RPMI1640 medium supplemented with $10 \%(\mathrm{v} / \mathrm{v})$ fetal bovine serum
(Cosmo Bio, Tokyo) under an atmosphere of $95 \%$ air and $5 \%$ $\mathrm{CO}_{2}$ at $37^{\circ} \mathrm{C}$ and seeded at $5 \times 10^{5}$ cells $/ \mathrm{ml}$ in 96 -well plates. After $24 \mathrm{~h}$, they were treated with varying amounts (100$1.56 \mu \mathrm{g} / \mathrm{ml}$ ) of 36 compounds including 3 dissolved in $1 \%$ dimethyl sulfoxide (DMSO, data not shown). The sensitivity of the colon cancer cells (SW480, DLD-1, and COLO201) to $\mathbf{1}-\mathbf{3}$ is shown in Table 1 . After $72 \mathrm{~h}$ of treatment, the number of the cells were determined by the trypan blue dye-exclusion test. The time-dependent decreases in the percentage of cell number after treatment with $\mathbf{2}$ are shown in Fig. 2. For examination of apoptosis induced by $\mathbf{2}$ $(5 \mu \mathrm{g} / \mathrm{ml})$, Hoechst 33342 nuclear staining at $37^{\circ} \mathrm{C}$ for 30 min and the analysis of nucleosomal DNA fragmentation by agarose gel electrophoresis were performed.

We found that $\mathbf{1}-\mathbf{3}$ displayed cytotoxicity against the three colon cancer cell lines and that $\mathbf{2}$ exerted the most potent cytotoxic effect. Considering the molecular weight (1, 2, $906 ; \mathbf{3}, 228$ ), the cytotoxicity of $\mathbf{2}$ was $20-40$ times higher than that of 3 in DLD-1 and COLO201 cells. As shown in Fig. 2, the growth of all cell lines was markedly inhibited in a similar profile after 2 exposure compared with that of untreated control cells. The $\mathbf{2}$-induced growth inhibition was concentration dependent (data not shown). After treatment with $5 \mu \mathrm{g} / \mathrm{ml}$ of 2 for $48 \mathrm{~h}$, we observed the typical morphological characteristics of apoptosis, such as nuclear condensation and fragmentation as assessed by Hoechst 33342 staining in the majority of the floating detached cells in the three cell lines. A representative case of SW480 cells, which were most sensitive to 2, is shown in Fig. 3A. Furthermore, DNA ladder formation was found in DNA extracted from SW480 cells treated with $5 \mu \mathrm{g} / \mathrm{ml}$ for $48 \mathrm{~h}$ (Fig. 3B). DNA ladder formation was also observed in DLD-1 and COLO201 cells treated with $5 \mu \mathrm{g} / \mathrm{ml}$ of 2 (data not shown). The DNA ladder formation was induced by $\mathbf{1}$ or $\mathbf{3}$ in SW480 cells and was compatible with cytotoxicic potency. Thus a novel stilbenoid tetramer of $\mathbf{2}$ was found to induce cell death through apoptosis in human colon cancer cell lines. The screening experiment showed that the sensitivity of colon cancer cell lines to $\mathbf{2}$ was higher than that of other human tumor cell lines tested. Compound $\mathbf{2}$ was much more effective than $\mathbf{3}$, a representative naturally occurring cancer chemopreventive agent. $\left.{ }^{6}\right)$ Although both vaticanols $(\mathbf{1}, \mathbf{2})$ are composed of four identical units (Res. A-Res. D) which form two dihydrobenzofuran moieties, their sensitivity for human colon cancer cells are different. This suggests that a framework of dibenzobicyclo[3.2.1]octadien in 2 (Res. A and B in Fig. 1) contributes

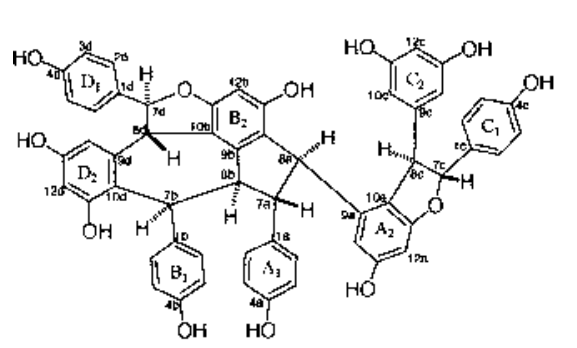

Vaticanol $B(1)$

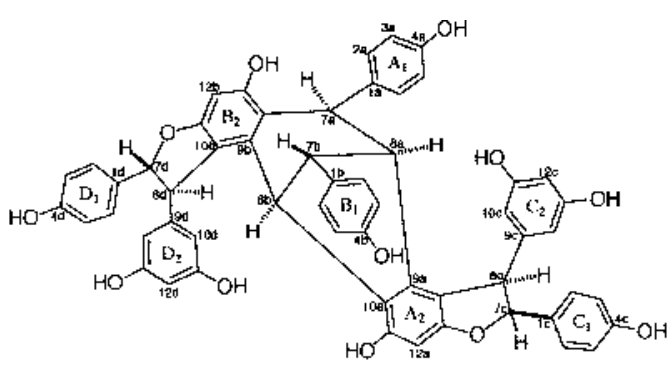

Vaticanol C (2)

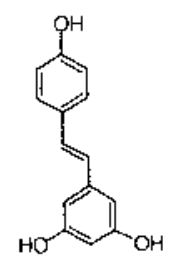

Resveratrol (3)

Fig. 1. Structure of Compounds $\mathbf{1}-\mathbf{3}$ 
Table 1. In Vitro Cytotoxicity Assay of Compounds $\mathbf{1}-\mathbf{3}$ against the Human Colon Cancer Cell Lines SW480, DLD-1, and COLO201

\begin{tabular}{|c|c|c|c|c|c|c|c|c|c|c|}
\hline & & 100 & 50 & 25 & 12.5 & 6.25 & 3.13 & 1.56 & ount. & \multirow[t]{10}{*}{$(\mu \mathrm{E}: \mathrm{ml})$} \\
\hline \multirow[t]{3}{*}{54460} & ! & ++ & + & + & - & - & - & - & - & \\
\hline & 2 & +++ & +++ & +++ & +++ & ++ & + & - & + & \\
\hline & 3 & +++ & +++ & ++ & + & + & - & - & - & \\
\hline \multirow[t]{3}{*}{ DLD.1 } & I & - & - & - & - & - & - & - & - & \\
\hline & 2 & +++ & ++ & ++ & + & + & - & - & - & \\
\hline & 3 & ++ & + & - & - & - & - & - & - & \\
\hline \multirow[t]{3}{*}{ COLO20J } & $\mathbf{I}$ & ++ & + & - & - & - & - & - & - & \\
\hline & 2 & ++ & ++ & ++ & + & + & - & - & - & \\
\hline & 3 & ++ & + & - & $=$ & $\therefore$ & . & - & + & \\
\hline
\end{tabular}

The viability of cells at $72 \mathrm{~h}$ after treatment was expressed as follows:,+++ 0 $25 \% ;++, 25-50 \% ;+, 50-100 \% ;-$, no apparent effect.

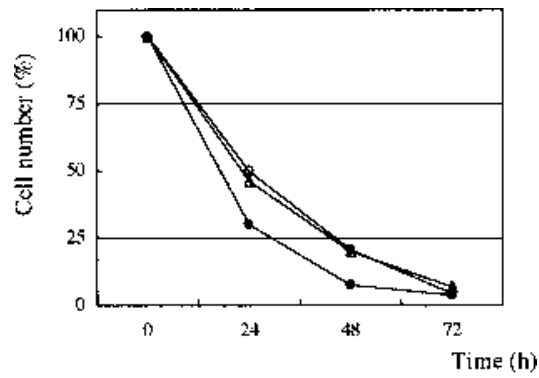

Fig. 2. Effect of $\mathbf{2}$ on Cell Growth of the Human Colon Cancer Cell Lines SW480, DLD-1, and COLO201 at Concentration of $5 \mu \mathrm{g} / \mathrm{ml}$

Cell numbers of three colon cancer cell lines after treatment with 2 were evaluated by the trypan blue dye-exclusion test and expressed as a percentage of the number in untreated cultures (control). $\bigcirc, \mathrm{SW} 480 ;-\mathrm{DLD}-1 ; \triangle \mathrm{COLO} 201$.
(A)

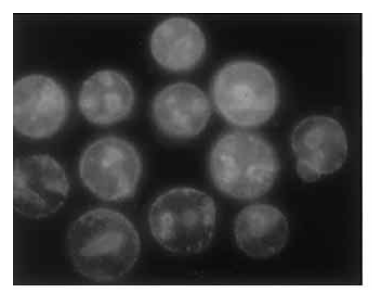

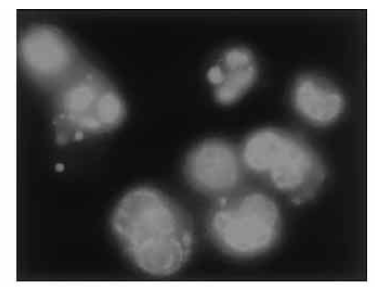

(B)

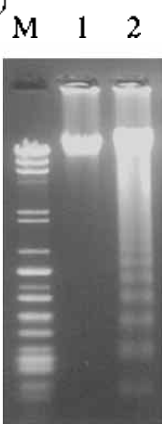

Fig. 3. Vaticanol C-Induced Apoptosis in SW480 Cells

(A) Morphological aspects of the cells. The cells were stained with Hoechst $33342(5 \mu \mathrm{g} / \mathrm{ml})$ for $30 \mathrm{~min}$ and then observed by fluorescence microscopy. Left, cells before treatment; right, after treatment with $5 \mu \mathrm{g} / \mathrm{ml}$ of $\mathbf{2}$ for $48 \mathrm{~h}$. (B) Nucleosomal DNA fragmentation of SW 480 cells after exposure to $5 \mu \mathrm{g} / \mathrm{ml}$ of $\mathbf{2}$. DNA $3 \mu \mathrm{g}$ was loaded into each lane. Lane 1, cells before treatment; lane 2, cells treated for $48 \mathrm{~h}$. Lane $\mathrm{M}$ is a DNA size marker.

to the higher cytotoxicity. It has been previously reported that 3 administration decreases the number of preneoplastic lesions in a murine model of chemically induced colon tumors, suggesting that the group of the 3-like compounds prevents initiation and promotion of carcinogenesis. ${ }^{7)}$ This effect seems to be related to the antioxidant properties of $\mathbf{3}$, which result either in protection against the carcinogen mutagenic action or in induction of phase II drug-metabolizing enzymes, potentiating the reactions of carcinogen detoxification. $\left.{ }^{6}\right)$ Accordingly, it remains to be clarified whether the antioxidant property of the compounds causes induction of apoptosis in established cultured cancer cell lines. As for the mechanisms of apoptosis by the stilbenoid compounds, 3 was suggested to induce apoptosis through $\mathrm{p} 53^{8)}$ and the mitochondrial pathway. ${ }^{9)}$ Although the potency of the stilbenoid compounds in inducing apoptosis may vary with the different cell lines, the findings presented in the current study suggest the possible chemopreventive and chemotherapeutic ability of 2. Thus the systematic analysis of these compounds will provide a useful clue for the development of the new anticancer drugs.

\section{REFERENCES}

1) Ito T., Tanaka T., Nakaya K., Iinuma M., Takahashi Y., Naganawa H., Ohyama M., Nakanishi Y., Bastow K. F., Lee K.-H., Tetrahedron, 57, 7309-7321 (2001).

2) Ohyama M., Tanaka T., Ito T., Iinuma M., Bastow K. F., Lee K.-H., Bioor. Med. Chem. Lett., 9, 3057-3060 (1999).

3) Tanaka T., Ito T., Nakaya K., Iinuma M., Riswan S., Phytochemistry, 54, 63-69 (2000).

4) Tanaka T., Ito T., Ido Y., Nakaya K., Iinuma M., Chelladurai V., Chem. Pharm. Bull., 49, 785-787 (2001).

5) Ito T., Tanaka T., Nakaya K., Iinuma M., Takahashi Y., Naganawa H., Ohyama M., Nakanishi Y., Bastow K. F., Lee K.-H., Tetrahedron Lett., 42, 5909-5912 (2001).

6) Jang M., Cai L., Udeani G. O., Slowing K. V., Thomas C. F., Beecher C. W. W., Fong H. H. S., Farnsworth N. R., Kinghorn A. D., Mehta R. G., Moon R. C., Pezzuto J. M., Science, 275, 218-220 (1997).

7) Tessitore L., Davit A., Sarotto I., Caderni G., Carcinogenesis, 21, $1619-1622$ (2000).

8) Huang C., Ma W., Goranson A., Dong Z., Carcinogenesis, 20, 237 242 (1999).

9) Tinhofer I., Bernhard D., Senfter M., Anether G., Loeffler M., Kroemer G., Kofler R., Csordas A., Greil R., FASEB J., 15, 1613-1615 (2001). 